\title{
Efektifitas E-LKPD berbasis Pendekatan Investigasi terhadap Kemampuan Berfikir Kritis Siswa Sekolah Dasar
}

\author{
Vivi Puspita, Ika Parma Dewi ${ }^{2}$ \\ ${ }^{1}$ Program Studi Pendidikan Guru Sekolah Dasar, Sekolah Tinggi Keguruan dan Ilmu Pendidikan (STKIP) Adzkia, \\ ${ }^{2}$ Program Studi Teknik Elektronika, Fakkultas Teknik, Universitas Negeri Padang (UNP) \\ Jl. Taratak Paneh No. 7 Kelurahan Korong Gadang Kecamatan Kuranji, Kota Padang \\ vivipuspita.pendas@gmail.com
}

\begin{abstract}
The problems in this study originated from the low ability of students to think critically in Mathematics in grade $\mathrm{V}$, including the low ability of students to focus on problems, determine settlement strategies and choose the right arguments to solve them. The study discusses whether there is an effect of students' critical thinking using E-LKPD based on a mathematical investigative approach. This type of research is a quasiexperiment. The study population was 140 grade V elementary school students. The research sample was 68 students. Collecting data in this study using learning outcomes tests in the form of descriptive questions as many as 5 items. The data obtained were tested for normality and homogeneity then analyzed using the t-test. In the experimental class, the highest score is 85 , the lowest score is 40 , the average is 70.37 , with a standard deviation of 9.36. In the control class, the highest score was 48.8, the lowest score was 5, with an average of 20.1 , with a standard deviation of 8.94. In the process, students in the experimental class showed better critical thinking skills than students in the control class. From the results of this study, it can be seen that the value of tcount $=41.12>$ table $=1.6687$, then the hypothesis or H1 is accepted, thus the use of E-LKPD based on a mathematical investigative approach has an effect on critical thinking skills.
\end{abstract}

Keywords: Critical thinking skills, E-LKPD, Mathematical Investigation Approach

\begin{abstract}
Abstrak
Permasalahan dalam penelitian ini berawal dari rendahnya kemampuan berpikir kritis siswa pada mata pelajaran Matematika kelas V, diantaranya rendahnya kemampuan siswa dalam memfokuskan pada permasalahan, menentukan startegi penyelesaian dan memilih argument yang tepat dalam penyelesaiannya. Penelitian membahas pengaruh berpikir kritis siswa dengan menggunakan E-LKPD berbasis pendekatan investigasi matematika. Jenis penelitian ini adalah quasi eksperimen. Populasi penelitian ini adalah 140 siswa sekolah dasar kelas V. Sampel penelitian adalah 68 siswa. Penelitian ini dilakukan pada tahun 2019 Pengumpulan data dalam penelitian ini menggunakan tes hasil belajar berupa soal uraian sebanyak 5 butir. Data yang diperoleh diuji normalitas dan homogenitasnya kemudian dianalisis menggunakan uji-t. Pada kelas eksperimen nilai tertinggi 85, nilai terendah 40, rata-rata 70,37, dengan standar deviasi 9,36. Pada kelas kontrol nilai tertinggi 48,8, nilai terendah 5, rata-rata 20,1, dengan standar deviasi 8,94. Dalam prosesnya, siswa di kelas eksperimen menunjukkan keterampilan berfikir kritis lebih baik dari siswa kelas kontrol. Dari hasil penelitian ini dapat diketahui bahwa nilai t_hitung $=41,12>$ tabel $=1,6687$, maka hipotesis atau $\mathrm{H}_{1}$ diterima, dengan demikian penggunaan E-LKPD berbasis pendekatan investigasi matematis berpengaruh terhadap keterampilan berpikir kritis.
\end{abstract}

Kata kunci: Keterampilan Berfikir Kritis, E-LKPD, Pendekatan Investigasi Matematika

Copyright (c) 2021 Vivi Puspita, Ika Parma Dewi

$\bowtie$ Corresponding author: Vivi Puspita

Email Address: vivipuspita.pendas@gmail.com (Jl. Taratak Paneh No. 7 Kelurahan Korong Gadang, Padang)

Received 11 Januari 2021, Accepted 08 Februari 2021, Published 08 Februari 2021

\section{PENDAHULUAN}

Pendidikan merupakan persoalan yang sangat penting bagi kemajuan suatu bangsa. Pendidikan harus mampu menghasilkan manusia yang berkualitas dan mampu bersaing dengan negara-negara lain disamping harus memiliki ilmu pengetahuan, budi pekerti luhur dan moral yang baik. Berbagai upaya dilakukan untuk meningkatkan kualitas pendidikan nasional. Sekolah sebagai salah satu lembaga 
pendidikan formal berupaya meningkatkan kualitas pendidikan, melalui pengembangan dan perbaikan kurikulum, perbaikan sarana dan prasarana pendidikan, pengembangan materi pembelajaran, serta pelatihan bagi guru.

Banyak faktor yang mempengaruhi kualitas pendidikan, diantaranya yaitu guru, siswa, pendekatan, maupun model pembelajaran yang digunakan. Guru memiliki peran yang besar dalam proses belajar mengajar. Selain memberikan pengetahuan guru juga membimbing siswa, mendorong potensi siswa membangun kepribadian siswa, serta memberikan motivasi siswa dalam belajar. Oleh karena itu guru harus memiliki kreativitas yang tinggi dalam menyampaikan materi pembelajaran agar siswa tertarik dan aktif dalam mengikuti pembelajaran yang disajikan guru. Matematika merupakan salah satu mata pelajaran yang sangat penting di sekolah dasar. Melalui matematika diharapkan siswa dapat menerapkannya dalam kehidupan sehari-hari. Oleh karena itu, matematika penting untuk dikuasai sejak dini. Diharapkan apabila siswa dapat menguasai matematika dengan baik, siswa juga dapat menguasai ilmu-ilmu yang lain dengan baik pula.

Pembelajaran matematika di sekolah dasar menunjukkan bahwa matematika tidak hanya sebatas penguasaan fakta dan prosedur matematika serta pemahaman konsep, tetapi juga berupa kemampuan keterampilan matematika yang lebih lengkap (Puspita, 2019). Keterampilan matematika dapat terbagi dua yaitu keterampilan tingkat tinggi dan keterampilan tingkat rendah. Karenanya siswa di sekolah dasar tidak hanya dituntut untuk mampu memiliki keterampilan tingkat rendah namun juga diharapkan mampu memiliki kemampuan tingkat tinggi, seperti halnya siswa mampu mamiliki keterampilan berpikir kritis dalam menyelesaikan sebuah masalah. Maka guru dituntut untuk mampu memfasilitasi siswa agar mampu memiliki keterampilan berpikir kritis.

Kemampuan berpikir secara kritis merupakan salah satu kecakapan hidup yang perlu dipelajari dan dikembangkan. Glaser (Fisher, 2008) menjelaskan berfikir kritis sebagai suatu sikap berfikir mendalam terhadap masalah serta menerapkannya dalam metode pemeriksaan dan penalaran yang logis. (Sukmadinata, 2012) berpikir kritis merupakan kecakapan dalam bernalar secara teratur. Artinya memiliki berfikir secara sistematis dalam menilai, memecahkan masalah, menarik keputusan, dan menyatakan keyakinan dengan bukti yang jelas. berpikir Kritis adalah aktivitas kognitif, yang terkait dengan penggunaan pikiran, Belajar untuk berpikir dengan cara kritis analitis dan evaluatif berarti menggunakan proses mental seperti perhatian, kategorisasi, seleksi, dan penilaian. (Cottrell, 2005)(Puspita et al., 2020).

Wahidin (Ahmatika, 2017) menjelaskan beberapa manfaat yang diperoleh dari pembelajaran yang menekankan pada proses keterampilan berpikir kritis, yaitu: pertama Belajar lebih ekonomis, yakni bahwa apa yang diperoleh dan pengajarannya akan tahan lama dalam pikiran siswa. Kedua Cenderung menambah semangat belajar dan antusias belajar siswa. Dengan berfikir kritis diharapkan siswa dapat memiliki sikap ilmiah, dan siswa memiliki kemampuan memecahkan masalah baik pada saat proses belajar mengajar di kelas maupun dalam menghadapi permasalahan nyata yang akan dialaminya. Mengingat banyaknya manfaat kemampuan berfikir kritis terhadap keberhasilan proses 
pembelajaran siswa maka pada sekolah dasar memiliki peran penting dalam melatih kemampuan berpikir kritis siswa. Asumsinya jika dari sekolah dasar telah dilatik untuk mampu berfikir secara kritis maka ke jenjang pendidikan yang lebih tinggi akan dapat memudahkan siswa dalam memahami pembelajaran khususnya matematika.

Manfaat keterampilan berfikir kritis nyata belum maksimal dilaksanakan di sekolah dasar. (Nurulaen, 2011) menjelaskan bahwa kemampuan berfikir kritis di sekolah dasar masih rendah khususnya pada materi aljabar dan geometri. (Nahdi, 2015) memaparkan temuan bahwa pembelajaran dengan berfikir kritis belum dibiasakan di sekolah dasar. (Ahmatika, 2017) (Eviyanti et al., 2020) menjelaskan aktivitas pembelajaran matematika di skeolah dasar cendrung teacher center, siswa diminta untuk mendengarkan penejasan yang dipaparkan oleh guru, dilanjutkan dengan mengerjakan latihan dan membahas kembali latihan secara klasikal. Proses tersebut mengindikasi bahwa pembelajaran yang dilakukan belum melibatkan kemampuan berfikir kritis. Hasil observasi yang dilakukan pada SD Negeri 10 Sungai Sapih menunjukkan rendahnya kemampuan berfikir kritis siswa.

Permasalahan di atas menunjukkan rendahnya aktivitas serta hasil belajar yang berbasis pada keterampilan berfikir kritis siswa. pendekatan investigasi matematika mampu menuntun siswa memiliki keterampilan berpikir kritis dalam menyelesaikan masalahnya. Investigasi matematika dilandaskan pada tugas pemecahan masalah yang dapat dispekulasi oleh siswa, ide-ide tes serta berhubungan dengan yang lainnya dalam mempertahankan solusi mereka masing-masing. Investigasi memberikan kesempatan kepada siswa untuk menganalisis suatu topik secara mendalam dan melakukan koneksi antara berbagai bentuk representasi, investigasi juga kaya dengan muatan matematika serta sangat membantu guru dan siswa agar menggunakan berbagai cara penyelesaian. (Turmudi, 2010) Usaha terbaik seorang guru dalam pembelajaran pembelajaran matematika yang merangsang siswa agar mencari secara mandiri, menggunakan penalara dalam melakukan penyelidikan guna melakukan pembuktian terhadap suatu masalah. Dapat diartikan bahwa pendekatan investigasi matematika memberikan peluang kepada siswa untuk menyelesaikan suatu masalah dengan caranya sendiri. Sehingga siswa akan mampu berpikir kritis dalam menyelesaikan masalah yang disajikan oleh guru.

Implementasi berfikir kritis menggunakan pendekatan investigasi dilakukan dalam bentuk ELKPD. Menurut (Trianto, 2013) Lembar Kerja Peserta Didik Elektronik (E-LKPD) merupakan rangkaian kegiatan yang digunakan siswa dalam melakukan penyelidikan dan penyelesaian masalah. sedangkan (Putriyana et al., 2020) (Umriani, 2020) menjelaskan E-LKPD berupa panduan kerja peserta didik untuk mempermudah siswa dalam memahami materi pembelajaran dalam bentuk elektronik yang pengaplikasiannya menggunakan desktop komputer, notebook, smartphone, maupun handphone. sekumpulan kegiatan mendasar yang harus dilakukan oleh siswa untuk memaksimalkan pemahaman dalam upaya mencapai tujuan pembelajaran. (Susilowati et al., 2017) menjelaskan temuan penelitian di sekolah dasar terkait rendahnya keterampilan siswa dalam mengerjakan soal berpikir kritis, oleh karenanya direkomendasikan untuk melakukan penelitian yang dapat 
meningkatkan keterampilan berpikir kritis siswa khususnya di sekolah dasar. Keterampilan berpikir kritis sangat baik digunakan dalam pembelajaran di kelas $\mathrm{V}$, karena dengan kegiatan berfikir kritis siswa akan mampu memecahkan masalah dengan langkah-langkah yang dapat melatih berfikir secara terstruktur.

(Kane et al., 2016) pada penelitiannya terkait pendekatan investigasi efektif untuk meningkatkan keterampilan berfikir kritis pada siswa mulai dari sekolah dasar sampai menengah atas. Pada pelaksanaannya siswa dengan keterampilan tinggi dapat menyelesaikan dengan baik. Sedangkan siswa dengan kategori sedang dan rendah memiliki hasil yang tidak signifikan. Hasil penelitian ( $\mathrm{K}$ et al., 2013) terhadap keterampilan berfikir kritis juga mendapatkah hal serupa, bahwa hasil belajar siswa setelah menggunakan Pendekatan Investigasi lebih baik dari sebelumnya. Selanjutnya respon siswa terhadap penggunaannya dalam pembelajaran juga Baik. Penelitian yang dilakukan (Eviyanti et al., 2020) di sekolah dasar dengan menggunakan pendekatan investigasi secara berkelompok menunjukkan hasil memiliki keterampilan berpikir yang lebih baik.

Penggunaan E-LKPD dalam pembelajaran memberikan dampak terhadap aktivitas belajar siswa menjadi lebih menyenangkan, membelajaran menjadi interaktif, memberikan keempatan kepada siswa untuk berlatih dan memotivasi siswa dalam belajar. (Nur Tita Adilla, 2016) menjelaskan bahwa E-LKPD dapat membantu siswa dalam memahami dan menumbuhkan rasa percaya diri dalam menyelesaikan soal berfikir kritis. selanjurnya (Febriyanti et al., 2017)menjelaskan kelemahan LKPD terletak pada interaksi oleh karenanya dibutuhkan pengembangan E-LKPD. selanjutnya (Umriani, 2020) menjelaskan perlunya merancang soal berfikir kritis dalam E-LKPD sebagai kegiatan melatih keterampilan berfikir kritis siswa. (Sapti, 2019) pada penelitiannya menunjukkan bahwa E-LKPD lebih menarik bagi siswa dan memberikan dampak terhadap hasil belajar siswa sekolah dasar. Dengan demikian penelitian ini bertujuan untuk mengetahui apakah terdapat pengaruh penggunaan E-LKPD berbasis pendekatan investigasi terhadap kemampuan berfikir kritis siswa sekolah SD.

\section{METODE}

Jenis penelitian yang digunakan pada penelitian ini merupakan penelitian eksperimen, variabel bebas pada penelitian ini adalah E-LKPD berbasis Investigasi. sedangkan variabel terikatnya adalah kemampuan berfikir kritis siswa. Pada pelaksanaannya satu kelas menggunakan E-LKPD (kelas eksperimen) dan kelas dengan pembelajaran yang digunakan di sekolah pada umumnya (control). Penelitian eksperimen memberikan perlakuan (treatment) yang hasilnya digunakan untuk mencari pengaruh perlakuan tertentu terhadap hal lain dalam kondisi yang terkendalikan. 


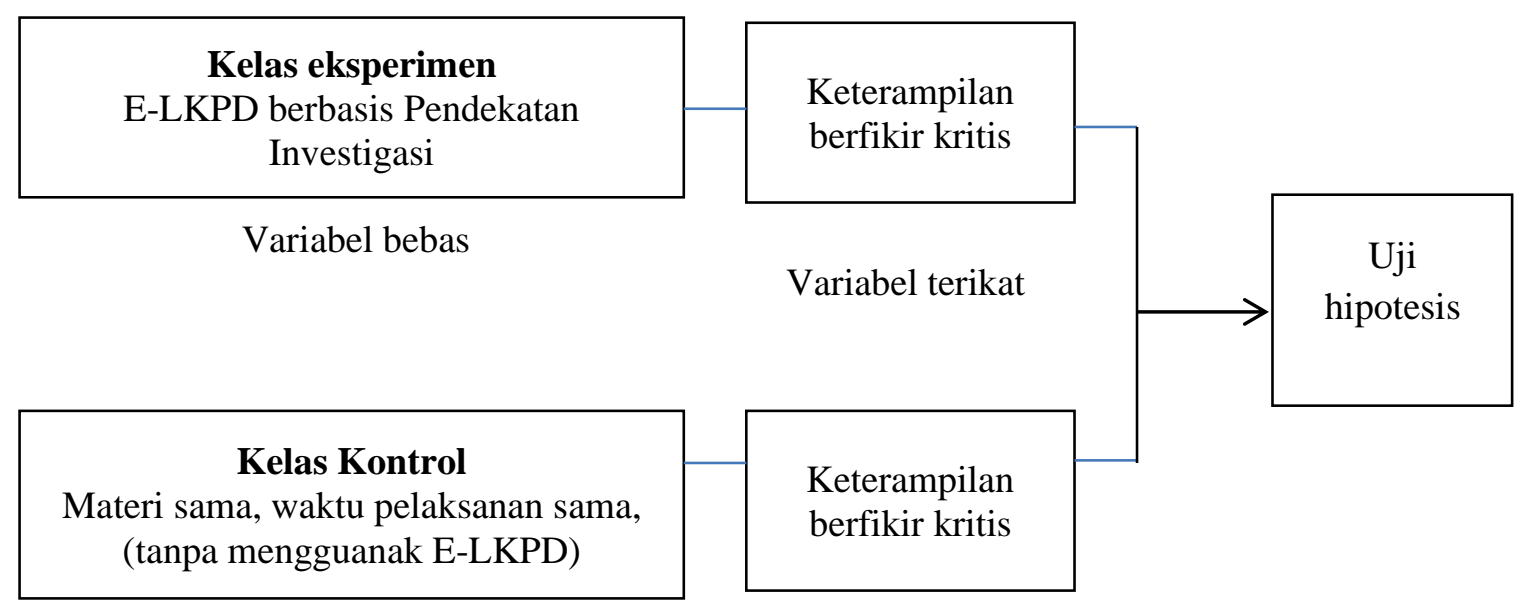

Variabel Kontrol

Bagan 1. Rancangan penelitian

Uji validitas terhadap instrument peelitian dilakukan dengan memberikan angket kepada ahli, pada aspek bahasa, desain dan materi. Hasil vaiditas E-LKPD secara keseluruhan memperoleh nilai valid. Validasi yang dilakukan ahli terhadap materi dan ketermuatan pendekatan investigasi memperoleh nilai 3,7 dengan kategori sangat valid. Hasil validitas terhadap desain memperoleh nilai 3,1 dengan kategori valid. Selanjutkan validasi terhadap bahasa diperoleh nilai 3,5 dengan kategori sangat sangat valid. Soal yang digunakan terlebih dahulu telah divaliasi oleh ahli guna menentukan ketermuatan dan kesesuai dengan penilaian dalam mengukur keterampilan berfikir kritis siswa.

Populasi dalam penelitian ini adalah seluruh siswa kelas V SD Negeri 10 Sungai Sapih kota Padang yang terdiri dari empat kelas yang terdaftar pada tahun ajaran 2019. Distribusi siswa setiap kelas dapat dilihat pada tabel berikut.

Tabel. 1. jumlah siswa kelas V SDN 10 Sungai Sapih Kota Padang

\begin{tabular}{|l|l|}
\hline Kelas & Jumlah siswa \\
\hline VA & 34 orang \\
VB & 34 orang \\
VC & 36 orang \\
VD & 36 orang \\
\hline Total & 140 orang \\
\hline
\end{tabular}

Sampel dari penelitian ini terdiri dari dua kelas yaitu VA dan VB. Sampel yang diambil harus representatif artinya benar-benar mencerminkan populasi. Data diperoleh dari hasil tes yang diberikan kepada siswa. Sebelumnya dilakukan Uji Coba Tes. Pemilihan soal yang memiliki kriteria yang baik, maka soal akan di uji cobakan terlebih dahulu dan kemudia dianalisis untuk mendapatkan soal mana yang memenuhi kriteria soal yang baik. Setelah uji coba telah dilakukan, maka perlu melakukan analisis soal tes untuk mengetahui apakah soal dapat dipakai, revisi, atau dibuang. Berikut merupakan contoh soal yang digunakan pada tes. Selanjutnya uji daya pembeda soal. Tujuan ditentukan daya pembeda soal adalah untuk mengetahui apakah soal dapat membedakan siswa kelompok tinggi 
dengan siswa kelompok rendah. Teknik Analisis Data yang dilakukan adalah Uji Normalitas, uji homogenitas serta uji hipotesis.
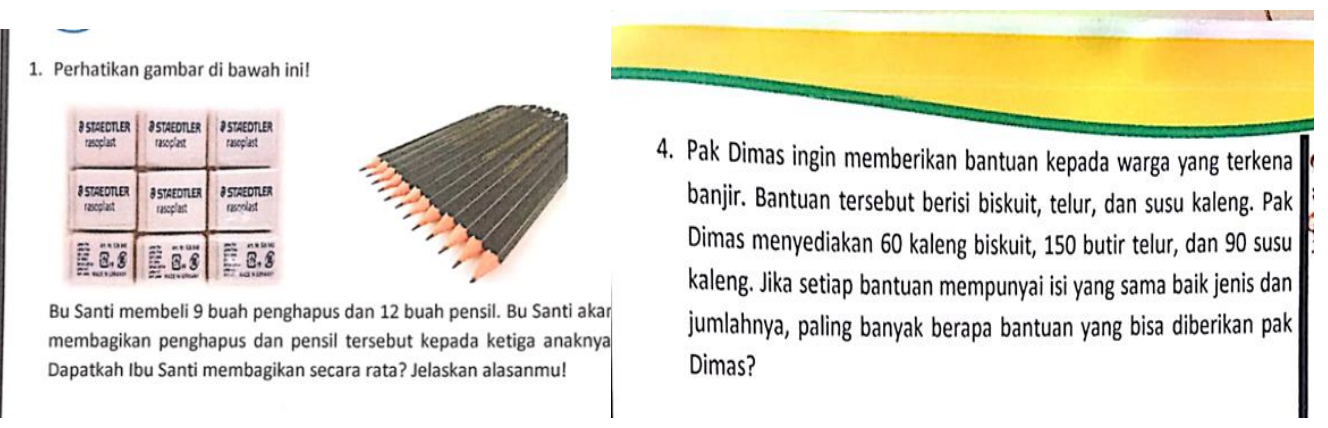

Gambar 1. Contoh Soal Yang Digunakan

\section{HASIL DAN DISKUSI}

Berdasarkan penelitian yang telah dilakukan pada kelas sampel, maka diperoleh data mengenai berfikir kritis siswa kelas V SDN 10 Sungai Sapih pada pembelajaran matematika. Data diperoleh melalui tes akhir yang dilakukan pada akhir penelitian. Soal tes akhir berupa esai sebanyak 5 butir soal, jumlah siswa pada kelas eksperimen yang mengikuti tes akhir sebanyak 34 orang dan jumlah siswa kelas kontrol yang mengikuti tes akhir berjumlah 34 orang.

Data berfikir kritis siswa pada pembelajaran matematika dengan materi menggunakan pecahan dalam penyelesaian masalah dapat dilihat dari tes akhir setelah diberikan perlakuan dengan menggunakan Pendekatan Investigasi Matematika pada kelas eksperimen dan pada kelas kontrol menggunakan metode konvesional. Dari tes akhir diperoleh nilai rata-rata $(\overline{\mathrm{X}})$ simpangan baku $(\mathrm{S})$, skor tertinggi $\left(\mathrm{X}_{\mathrm{maks}}\right)$ dan skor terendah $\left(\mathrm{X}_{\mathrm{min}}\right)$ terlihat pada tabel berikut:

Tabel 2. Perhitungan data tes akhir belajar matematika pada kelas sampel

\begin{tabular}{|c|c|c|c|c|c|}
\hline Kelas sampel & $\mathbf{N}$ & $\overline{\mathbf{X}}$ & \multicolumn{1}{|c|}{$\mathbf{S}$} & $\mathbf{X}_{\text {maks }}$ & $\mathbf{X}_{\text {min }}$ \\
\hline Eksperimen & 34 & 70.37 & 9.36 & 85 & 40 \\
\hline Kontrol & 34 & 20.1 & 8.94 & 48.8 & 5 \\
\hline
\end{tabular}

Pada tabel di atas terlihat bahwa rata-rata berfikir kritis matematika siswa kelas eksperimen $(\overline{\mathrm{X}}$ $=70.37)$ lebih tinggi dari rata-rata hasil belajar matematika siswa kelas kontrol $(\overline{\mathrm{X}}=20.1)$. Perbandingan rata-rata kelas eksperimen dan kelas kontrol dapat dilihat pada grafik berikut ini. 


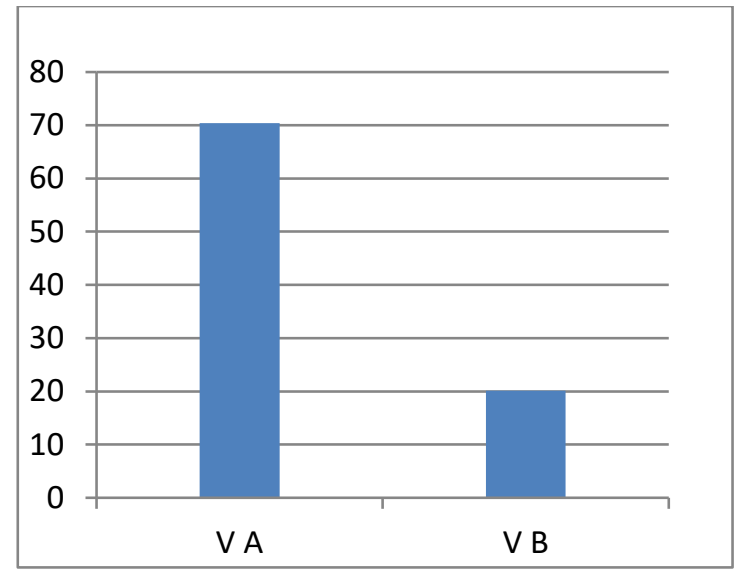

Grafik 1. Diagram Rata-Rata Nilai Kelas Eksperimen dan Kelas Kontrol

Tujuan analisis data pada penelitian ini adalah untuk mengetahui apakah berpikir kritis matematika siswa dengan menggunakan Pendekatan Investigasi Matematika lebih baik dari pada berpikir kritis matematika siswa dengan pendekatan konvensional. Untuk menguji hipotesis sebelum menarik kesimpulan, terlebih dahulu data yang dikumpulkan dianalisis. Uji hipotesis yang digunakan adalah uji-t syarat penggunaan uji-t bahwa data harus berasal dari populasi yang berdistribusi normal dan homogen dengan mengunakan aplikasi SPSS 21 sebagai berikut:

\section{Uji Normalitas Tes Akhir}

Pada penelitian ini, uji normalitas bertujuan untuk mengetahui apakah data berdistribusi normal atau tidak. Uji normalitas yang dilakukan penulis menggunakan Software SPSS 21. Hasil uji normalitas yang diperoleh yaitu:

Tabel 3. Hasil Uji Normalitas Tes Berfikir Kritis

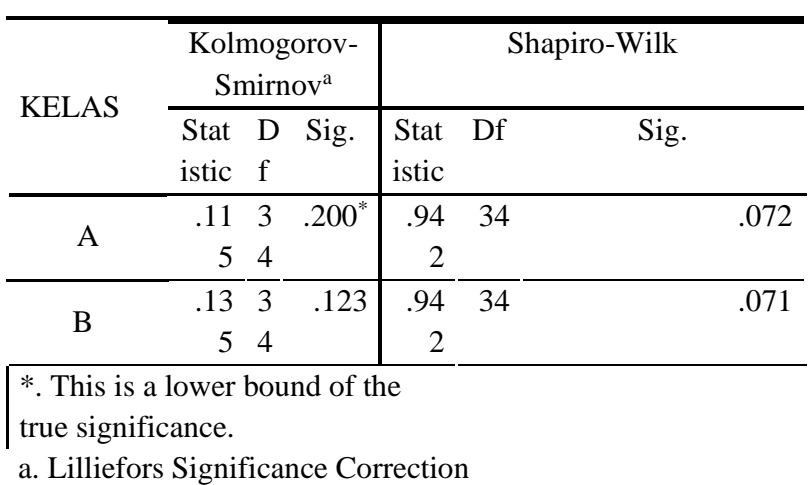

Berdasarkan tabel di atas nilai signifikan yang diperoleh pada keterangan kolom kolmogrof-smirnov 0,200 pada kelas eksperimen dan 0,123 pada kelas kontrol > 0,05 (taraf tingkat kesalahan/penolakan), maka dapat dikatakan bahwa data tes berfikir kritis berdistribusi normal. Menurut (Supardi, 2013) uji kolomogorov-sminov dilakukan apabila data yang diuji merupakan data tunggal atau data berfrekuensi tunggal, bukan dalam distribusi frekuensi kelompok. 


\section{Uji Homogenitas Tes Akhir}

Hasil perhitungan uji homogenitas variansi kedua kelas sampel dengan menggunakan uji lavence dapat dilihat pada tabel di bawah ini:

Tabel 12. Hasil Uji Homogenitas Tes Berfikir Kritis

\begin{tabular}{|c|c|c|c|}
\hline $\begin{array}{c}\text { Levene } \\
\text { Statistic }\end{array}$ & df1 & Sig. & \\
\hline .049 & 1 & 6 & .825 \\
\hline
\end{tabular}

Berdasarkan tabel di atas terlihat signifikan dari uji lavence adalah 0,825 >0,05 (taraf tingkat kesalahan/penolakan) maka dapat dikatakan bahwa data tas berfikir kritis berdistribusi normal.

\section{Pengujian Hipotesis}

Setelah data tes akhir berfikir kritis matematika siswa dihitung berdistribusi normal dan homogen, maka pengujian hipotesis akhir dilakuan dengan mengguakan uji t-test. Uji t-test dilakukan dengan cara membandingkan data dua kelompok sampel, atau membandingkan data antara kelompok eksperimen dengan kelompok kontrol, atau membandingkan peningkatan data kelompok eksperimen dengan peningkatan data kelompok kontrol yang telah normal dan homogen. Berdasarkan analisis data yang telah didapatkan, terlihat bahwa ada pengaruh keterampilan berpikir kritis siswa pada kelas eksperimen yang belajar dengan menggunakan Pendekatan Investigasi Matematika dengan siswa kelas kontrol yang menggunakan pendekatan konvensional pada pembelajaran matematika. Hal ini dapat dilihat dari rata-rata kelas eksperimen 70.37 dan kelas kontrol 20.1. Perbedaan tersebut dapat dilihat melalui uji hipotesis yaitu uji t-test. Dimana pada uji t-test diperoleh $t_{\text {hitung }}=41.12>t_{\text {tabel }}=$ 1.66827. Dengan demikian berarti $H_{o}$ ditolak dan $H_{1}$ yang berbunyi "terdapat pengaruh pada Pendekatan Investigasi matematika terhadap keterampilan berpikir kritis siswa pada kelas V SD Negeri 10 Sungai Sapih". Diterimanya $H_{1}$ menunjukkan bahwa pembelajaran dengan menggunakan ELKPD berbasis Pendekatan Investigasi matematika ini dapat diterapkan di sekolah untuk meningkatkan keterampilan berpikir kritis matematika siswa.

Hasil keterampilan berpikir kritis matematika siswa yang diajarkan dengan menggunakan ELKPD berbasis Pendekatan Investigasi matematika lebih tinggi dibandingkan dengan keterampilan berpikir kritis yang diajarkan dengan metode konvensional. Pembelajaran dengan menggunakan Pendekatan Investigasi matematika meminta siswa untuk berpikir kritis dalam memecahkan masalah. Sesuai dengan hasil penelitian ( $\mathrm{K}$ et al., 2013) memaparkan lembar kerja peserta didik dengan menggunakan pendekatan investigasi memberikan dampak positif terhadap keterampilan berpikir kritis siswa. (Kane et al., 2016) menjelaskan dalam peneliriannya bahwa penggunaan pendekatan investikasi akan melibatkan pemikiran matematis berdasarkan empat proses dasar yaitu sistematis, generalisasi, spekulasi dan menjelasan yang masuk di aka. Dengan demikian pembelajaran dilakukan dari level yang paling mudah ke yang sulit bagi siswa.

Berbeda dengan kelas ekspersimen, kelas kontrol menggunakan pendekatan konvensional 
dilaksanakan dengan mendengarkan penjelasan guru, dilanjutkan dengan latihan dan pembahasan latihan. Hasil yang didapat menunjukkan siswa kurang termotivasi dalam memecahkan masalah. Analisis jawaban yang diperoleh pada kelas kontrol menujukkan bahwa siswa belum terlatih untuk memecahkan masalah dengan runtut. Dengan demikian jika dibandingkan dengan kelas control proses pembelajaran menggunakan pendekatan Investigasi Matematika sangat baik diterapkan pada pembelajaran matematika terutama pemecahan masalah dan berfikir kritis dalam matematika. (Lorentzen, 2013) keterampilan berfikir kritis sangat berguna bagi siswa kedepannya, oleh sebab itu keterampilan berfikir kritis harus di kembangkan dalam kurikulum inti pembelajaran khususnya matematika. (Wulandari \& Suparman, 2019) memaparkan indicator dalam mengukur keterampilan berpikir kritis siswa yaitu 1) Identifikasi kebenaran yang diberikan dengan jelas dan rasional. 2) Mendeskripsikan masalah utama secara akurat. 3)Terapkan metode yang telah dipelajari secara tepat. 4) Mengungkapkan data / definisi / teorema dalam menyelesaikan masalah secara akurat. 5) Putuskan dan lakukan dengan benar. 6) Mengevaluasi argumen yang relevan dalam menyelesaikan masalah dengan hati-hati. 7) Bedakan antara kesimpulan yang didasarkan pada pemikiran yang valid / tidak valid.

E-LKPD berbasis pendekatan investigasi diawali dengan memberikan permasalahan yang membutuhkan investigasi kepada siswa, dalam pemberian permasalahan investigasi menggunakan soal terbuka. (Yudhanegara \& Lestari, 2015) menjelaskan sebagai proses terbuka maksudnya adalah tipe soal yang diberikan mempunyai banyak cara penyelesaian yang benar; hasil akhir yang terbuka maksudnya adalah tipe soal yang diberikan mempunyai jawaban yang banyak; cara pengembangan lanjutannya terbuka adalah ketika siswa telah selesai menyelesaikan masalah awal dan mereka mencoba menyelesaikan masalah baru dengan mengubah kondisi dari masalah yang pertama (asli).

Keterbatasn penelitian ini adalah belum adanya mengukur keterampilan berpikir kritis siswa dengan berbagai kategori contoh siswa dengan kemampuan tinggi,sedang dan rendah. Selanjutnya perlu diberikan angket kepada siswa untuk mengetahui respon siswa setelah menggunakan E-LKPD berbasis investigasi.

\section{KESIMPULAN}

Berdasarkan hasil penelitian yang penulis lakukan, dapat diambil kesimpulan bahwa diperoleh data nilai Signifikansi dengan $t_{\text {hitung }}=41.12>t_{\text {tabel }}=1.66827$. Maka dapat disimpukan bahwa $\mathrm{H}_{1}$ diterima atau terdapat pengaruh Pendekatan Investigasi matematika terhadap keterampilan berfikir kritis pembelajaran matematika siswa. Dari hasil penelitian terbukti bahwa Pendekatan Investigasi matematika memberikan pengaruh terhadap keterampilan berpikir kritis pembelajaran matematika siswa. 
Efektifitas E-LKPD berbasis Pendekatan Investigasi terhadap Kemampuan Berfikir Kritis Siswa Sekolah Dasar, Vivi

\section{UCAPAN TERIMA KASIH}

Ucapan terimakasih kepada pihak-pihak yang telah membantu dalam menyelesaian penelitian ini, diantaranya SDN 10 sungai Sapih Kota padang sebagai tempat penelitian dilakukan.

\section{REFERENSI}

Ahmatika, D. (2017). Peningkatan Kemampuan Berpikir Kritis Siswa Dengan Pendekatan Inquiry/Discovery. Euclid, 3(1), 394-403. https://doi.org/10.33603/e.v3i1.324

Cottrell, S. (2005). Critical Thinking Skill. Palgrave Macmillan.

Eviyanti, C. Y., Rista, L., Hadijah, S., \& Matematika, P. (2020). Penerapan Model Pembelajaran Investigasi Kelompok Melalui Media Domino Matematika. 04(02), 999-1010.

Febriyanti, E., Dewi, F., \& Afrida. (2017). Pengembangan E-LKPD Berbasis Problem Solving Pada Materi Kesetimbangan Kimia. Universitas Jambi.

Fisher, A. (2008). Berfikir Kritis Sebuah Pengantar. Gelora Aksara Pratama.

K, D. E., Ngazizah, N., \& Kurniawan, E. S. (2013). Pengembangan Lembar Kerja Siswa ( LKS ) dengan pendekatan investigasi kelompok guna mengoptimalkan keterampilan berkomunikasi dan berfikir kritis siswa kelas XI SMA Negeri 2 Purworejo tahun pelajaran 2012 / 2013. Radiasi, 3(1), 63-67. http://ejournal.umpwr.ac.id/index.php/radiasi/article/view/659

Kane, S. N., Mishra, A., \& Dutta, A. K. (2016). Preface: International Conference on Recent Trends in Physics (ICRTP 2016). Journal of Physics: Conference Series, 755(1). https://doi.org/10.1088/1742-6596/755/1/011001

Lorentzen, L. (2013). Limiting Behavior of Random Continued Fractions. Constructive Approximation, 38(2), 171-191. https://doi.org/10.1007/s00365-013-9198-y

Nahdi, D. S. (2015). Meningkatkan Kemampuan Berpikir Kritis Dan Penalaran Matematis Siswa Melalui Model Brain Based Learning. Jurnal Cakrawala Pendas, 1(1). https://doi.org/10.31949/jcp.v1i1.341

Nur Tita Adilla, D. (2016). Pengembangan Electronic Lembar Kerja Peserta Didik (E-LKPD) Berbasis Guided Inquiry Materi Kelarutan Dan Hasil Kali Kelarutan. 1-6.

Nurulaen, Y. (2011). Edisi Khusus No. 2, Agustus 2011. Jurnal Penelitian Pendidikan, Edisi Khus(2), $154-163$.

Puspita, V. (2019). DEVELOPING STUDENT' S REASONING SKILLS BY USING MODIFIED. December.

Puspita, V., Yuhelman, N., \& Rifandi, R. (2020). Dampak Pendekatan Realistic Mathematics Education Terhadap Keterampilan Berpikir Kritis Pada Siswa Sekolah Dasar. Justek: Jurnal Sains Dan Teknologi, 1(2), 20. https://doi.org/10.31764/justek.v1i2.3735

Putriyana, A. W., Kholillah, K., \& Auliandari, L. (2020). Kelayakan Lembar Kerja Peserta Didik Berbasis Model Pembelajaran Search, Solve, Create and Share pada Praktikum Materi Fungi. Biodik, 6(2), 1-12. https://doi.org/10.22437/bio.v6i2.9255

Sapti, M. (2019). Pengembangan E-LKPD Matematika Berbasis Penguatan Pendidikan Karakter (PPK) Kelas V SD. Kemampuan Koneksi Matematis (Tinjauan Terhadap Pendekatan Pembelajaran Savi), 53(9), 1689-1699. 
Sukmadinata. (2012). Kurikulum dan Pembelajaran Kompetensi. Refika Aditama.

Supardi. (2013). Analisis Statistik dalam Penelitian Konsep Statistik yang Lebih Komprehensif. Change Publication.

Susilowati, Sajidan, \& Ramli, M. (2017). Analisis keterampilan berpikir kritis siswa madrasah aliyah negeri di Kabupaten Magetan. Seminar Nasional Pendidikan Sains 2017 Dengan Tema "Strategi Pengembangan Pembelajaran Dan Penelitian Sains Untuk Mengasah Keterampilan Abad 21 (Creativity and Innovation, Critical Thinking and Problem Solving, Communication, Collaboration/4C)', 21(2000),

$223-231$. http://www.jurnal.fkip.uns.ac.id/index.php/snps/article/viewFile/11417/8102

Trianto. (2013). Mendesain Model Pembelajaran Inovatif, Progresif. Konsep, Landasan, dan Implementasinya Pada Kurikulum Tingkat satuan Pendidikan (KTSP). Kencana Prenada Media Group.

Turmudi. (2010). Matematika Eksploratif dan Investigatif. PT leuser Cita Pustaka.

Umriani, F. S. (2020). Studi Pendahuluan: E-LKPD Berbasis PBL untuk Meningkatkan Kemampuan Literasi Matematis Peserta Didik. JKPM (Jurnal Kajian ..., 2682(1), 131-140. https://journal.lppmunindra.ac.id/index.php/jkpm/article/view/8169

Wulandari, H., \& Suparman. (2019). Analisis Kebutuhan E-Book untuk Menstimulus Berpikir Kreatif. Proceedings of The 1st STEEEM 2019, 1(1), 162-167.

Yudhanegara, M. R., \& Lestari, K. E. (2015). Meningkatkan Kemampuan Representasi Beragam Matematis Siswa melalui Pembeajaran Berbasis Masalah Terbuka (Penelitian Kuasi Eksperimen terhadap Siswa Kelas VII SMPN 1 Pagaden, Subang). Jurnal Ilmiah Solusi, 1(4), 97-106. 